\title{
ASIMILASI NILAI KEKELUARGAAN LINTAS ETNIK
}

\author{
Wanto Rivaie*
}

\begin{abstract}
Indonesian people comprises of a lot of ethnic groups and some of them stay and live together sharing the same area. As each of the ethnic groups has specific culture and value, this research wanted to know how the value of family relationship assimilated across the ethnic groups, particularly among Dayaks, Melayunese, and Javanese transmigrants in Rasau Jaya village, Kubu Raya District, West Kalimantan. The research conducted in 2010 aimed at identifying, describing, and analyzing the cross ethnic assimilation process of the family relationship value. To meet the purpose of the research, analysis model based on Peter Blau's theory was employed and descriptive naturalistic method was used. The data were collected by using interview, structured observation, and document study techniques. The result of the research indicates that cross ethnic assimilation of family relationships value are done through value transformation and implementation, family union, appropriate moral value, democracy, togetherness, and solidarity. Various ethnic cultural backgrounds do not hinder the establishment of harmonious life of the ethnic groups. Based on the findings, the research provides a set of recommendations for the policy makers and further research.
\end{abstract}

Keywords: assimilation, family-relationship value, ethnic groups, transformation

\begin{abstract}
Abstrak
Bangsa Indonesia terdiri dari multietnik dan beberapa etnik hidup bersama di satu daerah dengan latar belakang budaya yang berbeda. Penelitian ini ingin mengetahui bagaimana terjadi asimilasi nilai kekeluargaan lintas etnik khususnya transformasi nilai kekeluargaan Dayak, Melayu, dan transmigran Jawa di Desa Rasau Jaya, Kabupaten Kubu Raya Kalimantan Barat. Penelitian yang dilakukan tahun 2010 bertujuan mengidentifikasi, mendeskripsikan, dan menganalisis proses asimilasi nilai kekeluargaan lintas etnik tersebut. Model analisis yang digunakan adalah teori Blau dan metode penelitian ini adalah deskriptif-naturalistik dengan pendekatan fenomenologis. Teknik pengumpulan data yang digunakan adalah wawancara mendalam, pengamatan/observasi terstruktur, dan dokumentasi. Data hasil penelitian menunjukkan bahwa proses asimilasi nilai-nilai kekeluargaan lintas etnik tersebut, melalui transformasi dan implementasi nilai, persatuan keluarga, nilai moral yang baik, musyawarah dan mufakat, kekerabatan dan solidaritas atau murah hati, telah berlangsung, dan terwujud dengan harmoni tanpa kendala yang berarti. Perbedaan-perbedan latar belakang kebiasaan, adat dan budaya, serta falsafah masing-masing etnik, tidak menjadikannya sebagai hambatan yang berarti. Kesamaan pemikiran yang ada, merupakan energi potensial dalam memperkokoh proses asimilasi lintas etnik antara Dayak, Melayu, dan Jawa. Penelitian ini memberikan rekomendasi kepada pembuat kebijakan, pengguna hasil penelitian ini, serta penelitian lebih lanjut.
\end{abstract}

Kata-kata Kunci: asimilasi, nilai kekeluargaan, etnik

\section{PENDAHULUAN}

\section{Latar Belakang Masalah}

Proses asimilasi nilai kekeluargaan dalam masyarakat multikultur seperti yang ada dan hidup di berbagai daerah di Indonesia, mengalami fluktuasi dari

\footnotetext{
* Dosen Pendidikan Sosologi Fakultas IImu Pendidikan Universitas Tanjungpura Pontianak Kalimantan Barat
}

waktu ke waktu. Rasau Jaya sebagai desa transmigran dari Jawa Timur sejak dibukanya pada tahun 1973 sampai saat ini belum pernah terjadi konflik dengan kekerasan. Dengan kata lain, desa ini mampu menjaga dinamika sosial yang akhir akhir ini sering mengalami fragmentasi antarkelompok maupun etnik. Beberapa 
hal lain yang patut dicatat di sini adalah desa tersebut kini mengalami perubahan yang signifikan terutama dalam hal berdirinya berbagai lembaga pemerintahan, lembaga pendidikan dan lembaga sosial dan keagamaan disamping adanya pembangunan fisik desa tersebut yang telah mengalami perubahan secara sangat berarti (Kades, 2010: 15).

Masyarakat modern saat ini dibangun dengan prinsip-prinsip rasionalitas, individualitas dan progresivitas, agar menjadi manusia yang kompetitif. Dengan demikian, harus meninggalkan nilai-nilai spiritualitas, komunalitas, dan harmoni. Hal itu karena masyarakat modern sangat mengandalkan kompetisi terhadap siapapun, sehingga manusia satu dengan yang lain ibarat serigala dengan serigala homo homini lupus (Hobbes, dalam Sofyan S., 2010:11-12), atau menganggap orang lain sebagai neraka (Sartre, 1936: 89). Memandang manusia lain sebagai pesaing, atau sebagai musuh telah diajarkaan sedemikian kuat dalam masyarakat modern.

Ketika seseorang memasuki pendidikan formal mulai diajarkan menjadi manusia individual dengan diperkenalkan bahwa ada tipe-tipe masyarakat yaitu masyarakat paguyuban dan masyarakat patembayan. Paguyuban dianggap perkumpulan yang hanya mengandalkan nilai-nilai emosional dan kekerabatan. Sementara masyarakat patembayan diangap manusia rasional yang berkumpul berdasarkan kepentingan tertentu. Perkumpulan ini tidak didasari atas rasa emosi, cinta kasih, tetapi atas dasar kepentingan dan fungsi-fungsi yang sangat rasional. Hal ini dianggap sebagai bentuk komunitas terbaik.

Dari situ kemudian beralih ke nilai kekeluargaan, dimana lazimnya terjadi berdasarkan ikatan cinta kasih, saling percaya, dan gotong royong, semakin hari semakin menipis, ditiadakan, sehingga filsafat Jawa yang menunjukkan tingginya komitmen sosial yang diungkapkan dalam kata hikmah "mangan ora mangan ngumpul", merupakan nilai komitmen dan perjuangan yang tidak kenal menyerah, justru dianggap sebagai kepasrahan. Padahal kata-kata itu merupakan terjemahan dari hikmah kenabian bahwa al-muslimu lil muslimi kal bunyan al-wahid (masyarakat muslim itu seperti sebuah bangunan) saling menopang, saling merasakan suka duka ditanggung dihadapi bersama. Dari sini ukhuwah islamiyah dan solidaritas sosial terbangun.

Davis (1941), Merton (1941), Kennedy (1944, 1952), Gordon (1964), Lieberson dan Waters (1988), seperti yang ditulis oleh Rossenfeld (2002: 153), menyatakan asumsinya bahwa perkawinan adalah merupakan suatu lembaga sosial dan keagamaan yang dipakai sebagai sebuah ukuran atau sebuah tongkat pengukur yang paling mendasar untuk mengetahui jarak sosial di antara kelompok-kelompok yang hidup dalam masyarakat, dan dengan menggunakan alasan-alasan yang rasional. Tidak hanya sebatas itu, perkawinan antaretnik juga merupakan sebuah simbol dari suatu proses sosial yang menunjukkan adanya sesuatu yang mewakili penerimaan dari luar ke dalam kelompok yang lebih intim dan suci daripada suatu tempat bekerja atau lingkungan tempat tinggal dari sebuah masyarakat. Tetapi pernikahan itu sendiri adalah lembaga sosial yang unik dan mempunyai sanksi hukum untuk prokreasi dan kemampuan untuk beranak (childbearing). Karena identitas ras dan etnis dan perbedaan yang diciptakan kembali dan direproduksi atau ditemukan kembali dalam proses melahirkan anak. Kehadiran pasangan yang kawin bisa mewakili tantangan yang unik tentang batas sosial antara kelompok orang tua dengan kelompok sosial yang lain.

Tidak adanya perkawinan antara dua kelompok etnik dapat mewakili dan mereproduksi adanya penghalang/jarak sosial di antara kelompok yang ada. Menurut Gordon (1964: 61) tentang asimilasi klasik dalam kehidupan masyarakat Amerika, ketika sebuah grup baru mulai untuk menikahi sepenuhnya dan bebas dengan kelompok sosial dominan yang asli, maka semua bentuk asimilasi sosial budaya akan selalu mengikuti. Akhirnya, lamanya suatu perpecahan antaretnik dan kelompok sosial di antara kelompok akan secara berangsur menghilang. Tetapi hal ini, oleh keilmuan modern disalahpahami sebagai paham organisme yang berdasarkan pada Darwinisme sosial. Padahal, ini merupakan nilai kekeluargaan, nilai-nilai komunal tempat bersemayamnya solidaritas dan cinta kasih antara manusia.

Di Amerika Serikat, sekarang hanya $25 \%$ dari anak-anak tinggal dalam keluarga dengan orang tua konvensional. Anak-anak menderita, kerusakan terbesar berasal dari keluarga berantakan. Semua cerita ini tidak tragis tetapi ketika melihat informasi sebagai agregat, kasus ini mencuat ke permukaan. Jumlah anak-anak yatim terus meningkat. Pada tahun 1960, 17,5\% dari anak-anak hidup tanpa ayah. Meskipun peningkatan dalam teknologi kedokteran dan harapan hidup, pada tahun 1990 , tercatat $36,3 \%$ anak yang tinggal jauh dari nenek moyang mereka. Blankenhorn (dalam Syah, 2010: 5) menyebutnya tren "berayah Amerika" dan "masyarakat yatim". Apa penyebab dari tren yang diperkirakan meningkat menjadi $50 \%$ di bagian awal abad ke-21? Blankenhorn dalam bukunya "yatim Amerika" menelusuri asal-usul kekerasan remaja, kekerasan dalam rumah tangga terhadap perempuan, 
pelecehan seksual anak, kehamilan remaja dan banyak masalah kejiwaan pada remaja untuk keluarga rusak dan tidak berayah (fatherlessness). Fenomena keluarga rusak dan fatherlessness terkait erat dengan hilangnya nilai kesucian dalam masyarakat.

Berikut ini beberapa konsekuensi lain dari sistem keluarga yang berantakan. Branden (dalam Syah, 2010: 6) mengutip Robert Reasoner, mantan pengawas sekolah sebuah distrik di California, dalam bukunya, "Enam Pilar Harga Diri" memaparkan "lebih dari 50 persen siswa telah melihat perubahan adanya pemisahan keluarga, perceraian, atau pernikahan kembali, di banyak kabupaten, pada sekolah tinggi tercatat 68 persen tidak hidup dengan dua orang tua sendiri. Dua puluh empat persen yang lahir di luar nikah dan tidak pernah mengenal ayah. Dua puluh empat persen dilahirkan bantalan efek residu dari penyalahgunaan obat oleh ibu. Di California, 25 persen terhindar dari pelecehan seksual atau fisik sebelum selesai SMA.

Sedangkan pada tahun 1890, 90 persen dari anak-anak, kakek-nenek tinggal di rumah, dan tahun 1950 tinggal 40 persen di rumah, hari ini angka itu turun menjadi 7 persen, sehingga ada jauh lebih sedikit dari sistem pendukung. Seperti pada kehidupan emosional anak muda, menganggap angka-angka ini. Tiga puluh sampai 50 persen akan bunuh diri. Lima belas persen akan membuat usaha serius untuk bunuh diri. Empat puluh satu persen minum banyak setiap dua-tiga minggu. Sepuluh persen dari anak perempuan akan menjadi hamil sebelum menyelesaikan sekolah tinggi. Tiga puluh persen anak laki-laki dan perempuan putus sekolah pada usia delapan belas tahun (Syah, 2010: 5-6).

\section{Rumusan Masalah Penelitian}

Dari uraian pada bagian latar belakang penelitian di atas, penelitian ini di arahkan untuk menganalisis proses asimilasi sebagai berikut.

1. Bagaimanakah proses asimilasi nilai-nilai kekeluargaan antara masyarakat Dayak dan Melayu, dengan warga transmigran Jawa Timur sehingga dapat hidup berdampingan secara manusiawi dan damai?

2. Bagaimanakah upaya menghilangkan kendalakendala antaretnik sehingga proses asimilasi yang telah ada bisa berjalan optimal?

3. Bagaimanakah peran tokoh formal dan informal, dalam proses transformasi nilai-nilai kekeluargaan untuk memperkecil kendala-kendala lintas etnik tersebut sehinggga terwujud proses asimilasi dalam masyarakat yang multikultur untuk memperkokoh integrasi nasional?

\section{Tujuan dan Manfaat Penelitian}

1. Umum

Merujuk pada perumusan masalah penelitian di bagian terdahulu maka tujuan penelitian ini adalah untuk menghasilkan gagasan dan pengembangan teori tentang proses asimilasi nilai kekeluargaan antara etnik Dayak, Melayu, dan Jawa, di desa transmigran Rasau Jaya, Kubu Raya Kalimantan Barat.

2. Khusus

Secara khusus tujuan penelitian ini diarahkan pada hal-hal sebagai berikut.

a. Mengidentifikasi dan menjelaskan serta menganalisis secara sistematis proses asimilasi nilai kekeluargaan lintas etnik antara masyarakat Melayu, Dayak, dan Jawa, di desa transmigran Jawa Timur Rasau Jaya.

b. Mengeksplanasi dan menganalisis berbagai kendala dalam proses asimilasi nilai kekeluargaan lintas etnik di desa Rasau Jaya.

c. Mengeksplorasi dan menjelaskan secara mendalam tentang upaya kepala desa dan tokoh masyarakat untuk mengatasi hambatan/kendala proses asimilasi nilai kekeluargaan lintas etnik di desa Rasau Jaya.

Kegunaan atau manfaat penelitian yang dilakukan oleh penulis meliputi dua macam manfaat, yaitu.

\section{Manfaat Teoretis}

Secara teoretis, kajian ini dapat mengembangkan gagasan, teori-teori, dan pengembangan model proses asimilasi nilai kekeluargaan lintas etnik, antara etnik Dayak, Melayu, dan Jawa di desa transmigran Jawa Timur, Rasau Jaya Kalimantan Barat.

\section{Manfaat Praktis}

Secara praktis, kajian ini dapat menjadi acuan para pengambil keputusan, dan para ilmuwan, serta akademisi yang bergelut dengan asimilasi nilai kekeluargaan lintas etnik, yang hidup dan berkembang di masyarakat Indonesia dan dunia intenasional yang bersifat multikultur. Dengan memahami berbagai unsur yang memberikan kontribusi dan yang menghambat terbentuknya asimilasi nilai kekeluargaan diharapkan dapat dilakukan sosialisasi yang efektif dan upayaupaya lainnya oleh para penentu kebijakan yang saling terkait, baik di sekolah, keluarga, dan masyarakat.

\section{KAJIAN TEORETIS}

Dalam bagian ini dipaparkan tentang teori-teori asimilasi dan nilai-nilai kekeluargaan sebagai upaya peneliti untuk lebih memahami fenomena dan permasalahan dalam penelitian ini. 


\section{Pengertian Asimilasi}

Istilah asimilasi berasal dari kata Latin, assimilare yang berarti menjadi asimilasi. Dalam bahasa Indonesia, sinonim kata asimilasi adalah "pembauran". Asimilasi merupakan proses sosial pada tahap lanjut (Gordon, 1964: 132-59; dalam Idi, 2009: 18).

Asimilation/asimilasi, dapat diartikan sebagai "...the reciprocal, involving mutual adjusment between host and migrant communities. In adition, assimilation is the processes by which immigrant groups were integrated into the dominant white culture" (Abecrombie. et.all,1988: 14). Asimilasi dapat dipahami sebagai pengaruh timbal balik/hubungan timbal balik, termasuk di antaranya suatu proses saling menyesuaikan antara masyarakat tuan rumah/setempat dan masyarakat pendatang.

Lebih lanjut, asimilasi merupakan suatu proses di mana kelompok pendatang (imigran) menyatu ke dalam budaya dominan kelompok kulit putih. Dalam teori Robert E. Park (1950) (dalam Idi, 2009: 17-18), tentang "race relation cycle" dijelaskan bahwa ...the social interaction between the host society and new immigrants was conceptualized in terms of four stages: contacts, competition, accomodation, and assimilation Hal ini senada seperti yang dikutip Lemore dari Park bahwa "... racial and etnic contact led to competition, accomodation, and assimilation, in that order"(Lemore, 1983:45)

"Asimilasi terdiri dari empat subproses: akulturasi, integrasi, amalgamasi/ penggabungan, dan identifikasi, yang masing-masing merupakan aspek budaya, struktural, biologis, dan psikologis (Gordon, 1981: 84110). Asimilasi nilai kekeluargaan lintas etnis dimaksudkan untuk menganalisis bagaimana transformasi nilainilai tersebut berlangsung di antara etnik Dayak-Jawa, Melayu-Jawa, dan Dayak-Melayu, di Desa Rasau Jaya Kabupaten Kubu Raya Kalimantan Barat.

\section{Nilai-Nilai Kekeluargaan}

Nilai-nilai kekeluargaan merupakan sesuatu yang luhur dan mulia. Sesuatu dikatakan luhur karena memiliki posisi dan harga yang tinggi di masyarakat. Nilai-nilai ini menjadi harapan bagi semua warga untuk membangun masyarakat agar hidup menjadi harmoni dan damai. Untuk lebih memahami makna yang terkandung dalam istilah tersebut maka berikut ini akan dipaparkan hal-hal yang yang dimaksud.

1. Nilai Moral dan Norma (NMNr)

Kehidupan ini dilingkari oleh berbagai nilai, tanpa nilai-nilai itu manusia kedudukannya sama dengan makhluk lain misalnya hewan. Nilai-nilai itu menjadi motivasi bagi manusia untuk mencapai kehidupan yang dicita-citakan.

\section{Pengertian}

Nilai, dapat diartikan sebagai sebuah harga. Nilai dapat disandarkan pada dua macam standar yaitu konkret dan abstrak. Standar nilai yang konkret seperti nilai produk suatu barang dan kesejahteraan. Di sisi lain, nilai berkaitan dengan gagasan/abstrak, seperti nilai kekeluargaan dan kasih sayang. Manusia dalam menjalani kehidupan ini diharapkan selalu menggunakan akal budi agar dalam mengejar keinginan, kebutuhan dan cita-cita hidupnya berpegang dengan nilai-nilai yag berlaku di tengah masyarakat. Hal ini sejalan dengan pendapat Purwahadiwardoyo (1965: 97) bahwa sumber nilai yang menjadi pedoman manusia untuk menjalani kehidupan sehari-hari, ada dua jenis.

a. Nilai Ilahiyah, dimaksudkan nilai yang mengandung kebenaran mutlak. Diturunkan melalui para Nabi dan Rasul yang wajib dilaksanakan setiap manusia, sebagai suatu perintah Tuhan. Misalnya, membaca dua kalimat syahadat, sholat, puasa, zakat, dan haji bagi yang mampu,

b. Nilai Insyaniah, dimaksudkan sebagai suatu nilai hasil kesepakatan manusia, yang selalu tumbuh dan berkembang sesuai kebutuhan masyarakat. Nilainilai ini akan tumbuh dan berkembang menjadi tradisi-tradisi dan norma-norma kemasyarakatan yang dihidupkan secara turun-temurun dari generasi yang satu ke generasi yang lain.

Dengan demikian dapat disimpulkan, bahwa dalam kehidupan ini, manusia perlu memperhatikan berbagai nilai agar hidupnya memiliki makna. Nilai-nilai yang perlu dipertimbangkan adalah menyangkut nilai yang konkret abstrak baik yang bersumber dari Illahi Rabbi maupun yang bersumber dari hasil kesepakatan manusia sendiri, agar dapat hidup layak sebagaimana manusia diciptakan sebagai khalifah di muka bumi ini.

3. Pengertian Kekeluargaan

Kekeluargaan, terdiri dari kata dasar keluarga yang memiliki makna sebagai berikut.

a. Merupakan kelompok sosial kecil yang umumnya terdiri dari ayah, ibu, dan anak.

b. Hubungan sosial di antara anggota keluarga relatif tetap dan didasarkan oleh ikatan darah, perkawinan, dan atau adopsi.

c. Hubungan anggota keluarga dijiwai oleh suasana kasih sayang dan rasa tanggung jawab.

d. Fungsi keluarga adalah merawat, memelihara, dan melindungi anak dalam rangka sosialisasinya, agar mampu mengendalikan diri dan berjiwa sosial (Khaeruddin, 2008: 3).

Dewantara (1962: 380-393) menyatakan, kata keluarga berasal dari perkataan kawula dan warga. Kawula berarti abdi, yang berkewajiban mengabdikan 
diri dan menyerahkan segala tenaganya kepada yang dianggap tuannya. Sebaliknya warga berarti anggota, yang berwewenang ikut mengurus, memimpin, dan menetapkan segala apa yang perlu dilakukan.

Dengan demikian, keluarga yaitu kumpulnya beberapa orang yang karena terikat oleh satu turunan lalu mengerti dan merasa berdiri sebagai suatu gabungan yang khas, pun berkehendak juga bersamasama memperteguh gabungan itu untuk kemuliaan satu-satunya dan semua anggota.

Dari kata dasar keluarga seperti telah dipaparkan di atas, maka terbentuklah kata kekeluargaan yang artinya:

"alam keluarga, suasana keluarga" yang dibawa masuk ke suasana pergaulan, di lingkungan tetangga, dan lingkungan masyarakat. Sama tetapi tidak serupa, yaitu "sistem Guan Sie" pada masyarakat Mandarin. Guan Sie mengutamakan kerabat dekat untuk melakukan kerja sama dalam berkarya, namun reward dan punishment dilaksanakan secara konsisten (Dwiarso, 2008: 374).

Asimilasi nilai kekeluargaan dalam penelitian ini dimaksudkan sebagai instrumen yang sangat strategis bagi integrasi berbagai kelompok sosial yang ada di masyarakat Indonesia yang bersifat plural. Dengan demikian, maka proses transformasi nilai-nilai kekeluargaan lintas etnik Dayak-Jawa, Melayu-Jawa, dan Melayu-Jawa, dapat berlangsung dengan lebih optimal.

Hadirnya asimilasi nilai kekeluargaan akan mampu mengurangi adanya jarak sosial. Terjadinya saling memahami antaretnik dan berbagai masalah sosial budaya yang ada di masyarakat akan menghilang bersamaan dengan semakin intensifnya proses asimilasi nilai kekeluargaan di kalangan berbagai etnik yang berbeda.

Menurut model teoretik Blau (1977: 98-99) seperti dikutip oleh Idi (2009: 40), menunjukkan bahwa masyarakat akan terintegrasi/terasimilasi apabila ada suatu keadaan yang dalam konteks struktur sosial menunjukkan kecenderungan parameter-parameternya saling berinterseksi. Sebaliknya bilamana keadaan struktur sosial menunjukkan parameter-peremeternya yang cenderung ke arah konsolidasi, maka integrasi/ asimilasi suatu masyarakat akan sulit terjadi.

Model analisis yang digunakan adalah Blau (1977: 98-99), yang menganalisis pengaruh budaya dominan dalam proses asimilasi. Blau lebih jauh menegaskan bahwa, dalam hubungan mayoritas dan minoritas, ukuran besar/kecilnya suatu kelompok mengindikasikan kemungkinan terjadinya integrasi-asimilasi, jika kelompok mayoritas merupakan penduduk asli, maka asimilasi kelompok etnis mayoritas lebih mungkin terjadi. Sebaliknya, jika kelompok mayoritas merupakan migran, maka asimilasi menurut Blau, lebih sulit terwujud.

Dengan demikian, asimilasi akan lebih mungkin terjadi di antara kelompok mayoritas (Melayu) dengan kelompok minoritas (Jawa). Manakala kelompok minoritas terjadi pada kelompok transmigran, akan lebih terasimilasi oleh kelompok mayoritas (Melayu atau Dayak). Dalam bahasa lain dapat diungkapkan di sini bahwa masyarakat transmigran Jawa Timur akan lebih terasimilasi oleh masyarakat Melayu atau Dayak, karena menurut Blau (1977: 98-99) Melayu atau Dayak adalah merupakan kelompok mayoritas yang memiliki budaya dominan dan akan mampu mewarnai kehidupan kelompok minoritas/subordinat yaitu orang-orang transmigran yang hidup di Rasau Jaya Kabupaten Kubu Raya, Kalimantan Barat. Dengan jumlah yang memang mayoritas dan budayanya telah mengakar pada masyarakat luas tersebut, maka akan mampu memengaruhi sikap dan perilaku kelompok minoritas tersebut.

\section{METODOLOGI PENELITIAN}

Untuk menjawab masalah penelitian ini maka studi ini akan difokuskan pada analisis tentang asimilasi nilai-nilai kekeluargaan masyarakat lokal (Dayak dan Melayu) dengan masyarakat pendatang yaitu transmigran dari Jawa Timur. Pendekatan yang digunakan adalah pendekatan kualitatif dengan jenis penelitian deskriptif. Rancangan penelitian kualitatif ini digunakan sebagai pendekatan utama, yang meliputi sejumlah strategi penelitian yang memiliki sejumlah sifat tertentu, yang diambil dari serangkaian asumsi yang saling berhubungan yang bersifat khas paradigma penelitian kualitatif (Mustafa dalam Alwasilah, 2008:26).
Teknik pengumpulan data penelitian menggunakan teknik langsung, yang diperoleh melalui berbagai instrumen penelitian menggunakan wawancara mendalam, pengamatan/observasi terstruktur dan juga dokumendokumen yang relevan. Data yang terkumpul dianalisis dan dideskripsikan serta dihubungkan antara fokus penelitian yang satu dengan yang lain. Di samping itu, data yang memerlukan penyelesaian secara statistik sederhana seperti persentase juga digunakan. Penelitian ini dimulai sejak Februari hingga November 2010 , di Desa Rasau Jaya Kalimantan Barat.

Analisis dan interpretasi data merupakan kegiat- 
an penelitian yang dimulai dengan perakitan materimateri mentah dan pengambilan suatu tinjauan mendalam atau gambaran total dari proses penelitian secara keseluruhan (Emzir, 2010: 174).

Analisis merupakan pengurutan data, penyusunan data ke dalam pola, kategori, dan satuan deskriptif dasar. Proses analisis melibatkan pertimbangan katakata, nada, konteks, nonverbal, konsistensi internal, frekuensi, perluasan, intensitas, kekhususan respons, dan ide-ide besar.

Data yang diperoleh melalui instrumen pengumpulan data, akan dianalisis yang bertujuan untuk mendapatkan informasi yang diinginkan. Data tersebut dideskripsikan. Masing-masing data yang diperoleh dari berbagai instrumen dalam penelitian ini akan dideskripsikan secara detail agar tercapai tujuan yang diinginkan. Data yang dianalisis juga akan dirujuk dengan proses aktualisasi nilai-nilai kekeluargaan dalam masingmasing keluarga etnik yang dikaji, agar dapat menjawab pertanyaan pada bagian rumusan masalah tersebut di atas. Dengan kata lain, analisis terfokus untuk menjawab masalah yang diajukan di bagian permasalahan.

Untuk mendapatkan suatu hasil analisis dan interpretasi yang baik atau valid harus diingat akan adanya faktor-faktor yang sangat mempengaruhi proses analisis adalah data collection, data reduction, data display, dan akhirnya sampai pada suatu konklusi akurat dan logis.

\section{HASIL PENELITIAN}

Dari hasil-hasil pembahasan seperti yang telah dipaparkan pada bagian di atas, maka pada bagian ini akan dipaparkan tentang temuan penelitian dan pengembangan-pengembangan dari teori asimilasi yang terdahulu.

\section{Temuan Penelitian}

Dari paparan secara teoretik maupun secara empiris pada bagian deskripsi data maupun pada bagian pembahasan, maka dapatlah dikemukakan temuan penelitian sebagai berikut.

1. Model Teoretik Asimilasi Nilai Kekeluargaan dalam Keluarga Melayu-Jawa.

Model teoritik dalam penelitian ini dimaksudkan sebagai suatu alur berpikir yang dilandasi oleh pendapat para ahli di bidang asimilasi nilai kekeluargaan, di mana teori-teori tersebut digunakan untuk menganalisis permasalahan yang terjadi pada asimilasi nilai kekeluargaan lintas etnik yaitu antara Melayu dengan Jawa, Dayak-Jawa Timur, dan Melayu-Dayak. Sementara model empirik dalam penelitian ini dimaksudkan sebagai hasil temuan penelitian di lapangan tentang asimilasi nilai kekeluargaan lintas etnik yang terjadi pada masing-masing keluarga kawin campur tersebut dibahas pada bagian deskripsi data dan pembahasan hasil penelitian.

Dengan demikian dapat diasumsikan disini, bahwa model-model yang dipaparkan dimungkinkan terdapat perbedaan antara model teoretik dengan model empirik penelitian. Namun demikian juga sangat dimungkinkan, terjadinya kesamaan antara model teoretik dengan model empirik dari suatu penelitian.

Terjadinya perbedaan atau persamaan antara kedua model tersebut dapat dipengaruhi oleh berbagai faktor, di mana hal tersebut akan dibahas secara rinci pada setiap model yang akan dipaparkan bagian berikut.

Model teoretik yang digunakan dalam menganalisis asimilasi nilai kekeluargaan antara MelayuJawa, Melayu-Dayak dan Dayak-Jawa adalah model dari Blau ( 1977: 98-99) sebagai berikut.

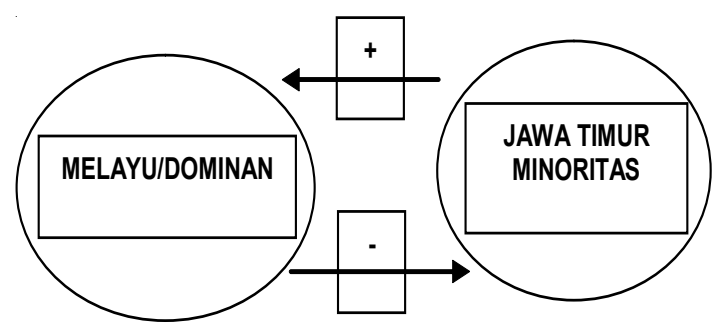

Gambar 1. Model Teoretik Asimilasi Blau (1977)

Menurut model teoritik Blau (1977: 98-99) seperti dikutip oleh Idi (2009: 40), yang terlihat pada gambar 1, menunjukkan bahwa masyarakat akan terintegrasi/ terasimilasi apabila ada suatu keadaan yang dalam konteks struktur sosial menunjukkan kecenderungan parameter-parameternya saling berinterseksi. Sebaliknya, bilamana keadaan struktur sosial menunjukkan parameter-peremeternya yang cenderung ke arah konsolidasi, maka integrasi/asimilasi suatu masyarakat akan sulit terjadi.

Blau menegaskan bahwa dalam hubungan mayoritas dan minoritas, ukuran besar/kecilnya suatu kelompok mengindikasikan kemungkinan terjadinya integrasi/asimilasi, jika kelompok mayoritas merupakan penduduk asli, maka asimilasi kelompok etnis mayoritas lebih mungkin terjadi. Sebaliknya, jika kelompok mayoritas merupakan migran, maka asimilasi menurut Blau, lebih sulit terwujud. 
Dengan demikian, asimilasi akan lebih mungkin terjadi di antara kelompok mayoritas (Melayu) dengan kelompok minoritas (Jawa), manakala kelompok minoritas terjadi pada kelompok transmigran, akan lebih terasimilasi oleh kelompok mayoritas (Melayu atau Dayak).

Dalam bahasa lain dapat diungkapkan di sini bahwa masyarakat transmigran Jawa Timur akan terasimilasi oleh masyarakat Melayu atau Dayak, karena menurut Blau (1977: 98-99), Melayu atau Dayak adalah merupakan kelompok mayoritas yang memiliki budaya dominan dan akan mampu mewarnai kehidupan kelompok minoritas/subordinat yaitu orang-orang transmigrasi yang hidup di Rasau Jaya Kabupaten Kubu Raya, di Kalimantan Barat. Dengan jumlah yang memang mayoritas dan budayanya telah mengakar pada masyarakat luas tersebut, maka akan mampu mempengaruhi sikap dan perilaku kelompok minoritas tersebut.

2. Model Empirik Hasil Penelitian Asimilasi Nilai Kekeluargaan dalam Keluarga Melayu-Jawa.

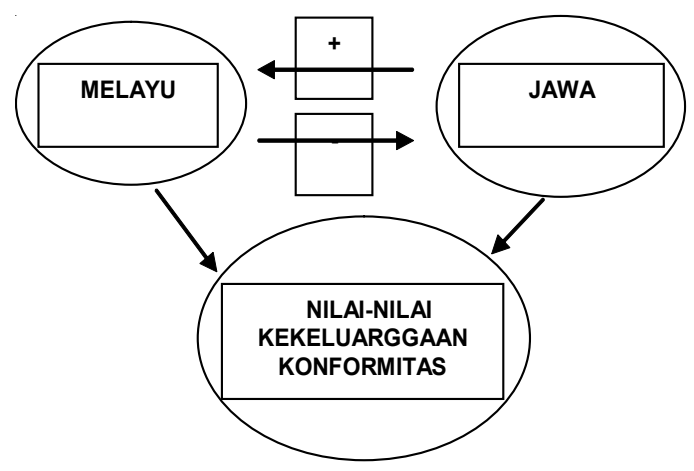

Gambar 2. Model Empirik Hasil Penelitian Asimilasi Nilai Kekeluargaan

Dari data empirik yang merupakan hasil temuan di lapangan, pada gambar 2 ternyata dalam keluarga Dadi-Suti (Melayu-Jawa), hidup dan berkembang pemikiran, sikap dan perilaku yang cenderung mengarah pada kebiasaan, adat Jawa yang dibangun melalui konformitas. Nilai-nilai kekeluargaan yang konformitas ini, dimaksudkan sebagai nilai-nilai yang dibangun bersama oleh suami-istri, dan juga oleh faktor kebiasaan, adat, dan lingkungan sosial budaya setempat antara Melayu dan Jawa, di mana keduanya saling memahami, saling menyesuaikan, dan melakukan kompromikompromi yang mengarah pada jalan tengah, rukun, dan sesuai etika kebijaksanaan (Haryono.P., 1993: 4446).

Sebagai contoh dalam melakukan transformasi dan penerapan nilai-nilai kekeluargaan, adalah yang berkenaan dengan sistem perkawinan yang dilakukan di Rasau Jaya. Kombinasi sistem perkawinan antara Melayu dan Jawa, dengan sistem menggunakan uang asap dapur sebagai bantuan calon suami kepada pihak mempelai calon istri. Hal ini merupakan adat dan kebiasaan warga Melayu yang mirip dengan tradisi etnik bangsa Arab yang beragama Islam. Sementara budaya Jawa dalam prosesi resepsi perkawinan biasanya pihak mempelai perempuan adalah yang membiayai sepenuhnya pesta perkawinan itu. Hal ini sebagai bagian proses transformasi dan implementasi dari nilai kekerabatan, yang intinya menguatkan kembali tali hubungan antarkerabat dari kedua belah pihak.

Faktor lain yang tak kalah pentingnya adalah keluarga Dadi menyesuaikan dengan kebiasaan dan adat kehidupan masyarakat Jawa Timur dalam memecahkan masalah-masalah tentang asimilasi nilai kekeluargaan lintas etnik tersebut, di mana keluarga Dadi mengadopsi nilai-nilai kekeluargaan Jawa. Hal ini bisa dimaklumi karena lingkungan sosial keluarga Dadi yang orang Melayu, hampir sepenuhnya didominasi lingkungan keluarga Jawa. Dengan demikian, keluarga Dadi hampir sepenuhnya mengadopsi nilai-nilai kekeluargaan Jawa dalam kehidupan sehari-hari.

Namun demikian, proses kawin campur/pembauran ini dengan seluruh aspek nilai-nilai kekeluargaan yang dipraktikan dalam kehidupan sehari-hari antara kedua kelompok lintas etnik, sebagaimana telah dipaparkan dalam bagian pembahasan, masing-masing rumpun etnik tersebut didasari oleh falsafah, kebiasaan dan adat yang relatif berbeda satu dengan yang lain, tetapi masing-masing etnik, memiliki hakikat nilai-nilai kekeluargaan yang sangat mirip. Dengan demikian, proses asimilasi keduanya tidak mengalami hambatan dan kendala yang berarti.

Temuan penelitian ini juga merupakan bagian dari pengembangan teori asimilasi yang terdahulu, yang memiliki fokus pembahasan yang relatif berbeda dengan yang dilakukan penulis lain. Sebagai contoh, teori asimilasi yang dijelaskan oleh Gordon (1964); Hirsman (1983); Yinger (1985); dan Kulczycki dan Lobo (2003: 203), memfokuskan pada tingkatan-tingkatan asimilasi.

Dalam penelitian ini juga ditemukan bahwa keluarga Dadi melakukan penyesuaian diri dengan kebiasaan dan adat yang berlaku di Desa Rasau Jaya, dengan menggunakan bahasa Jawa sebagai komunikasi antaranggota keluarga. Berbagai nilai keluarga yang dibangun berorientasi pada pada kehidupan sehari-hari yang terjadi di desa tersebut.

Untuk itu dalam gambar 2, Jawa diberi label mayoritas/dominan/superordinat, yang mengandung makna bahwa dalam transformasi dan implementasi nilai-nilai kekeluargaan di lingkungan keluarga kawin 
campur tersebut adalah cenderung berorientasi pada kebiasaan dan ada orang-orang Jawa, sementara kebiasaan dan adat Melayu di dalam keluarga campuran ini menjadi subordinat/minoritas. Alasan yang sederhana dan mudah terukur adalah lingkungan kultural dan sosial di Desa Rasau Jaya, adalah didominasi budaya Jawa.

3. Model Teoretik Asimilasi Nilai Kekeluargaan dalam Keluarga Dayak-Jawa.

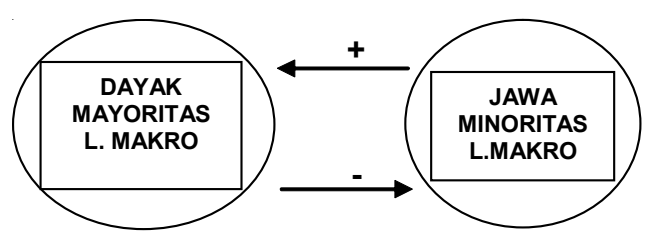

Gambar 3. Model Teoritik Asimilasi Blau (1977)

Menurut model teoritik Blau (1977: 98-99), seperti dikutip oleh Idi (2009: 40), yang terlihat pada gambar 3, menunjukkan bahwa masyarakat akan terintegrasi/terasimilasi, apabila ada suatu keadaan yang dalam konteks struktur sosial menunjukkan kecenderungan parameter-parameternya saling berinterseksi. Sebaliknya bilamana keadaan struktur sosial menunjukkan parameter-paremeternya yang cenderung ke arah konsolidasi, maka integrasi/asimilasi suatu masyarakat akan sulit terjadi.

Blau menegaskan bahwa dalam hubungan mayoritas (host-level makro) dan minoritas (transmigran-level makro), ukuran besar/kecilnya suatu kelompok mengindikasikan kemungkinan terjadinya integrasi/ asimilasi, jika kelompok mayoritas merupakan penduduk asli dalam konteks ini warga Dayak, maka asimilasi kelompok etnik mayoritas ke dalam etnik minoritas (transmigran-Jawa) lebih mungkin terjadi. Sebaliknya, jika kelompok mayoritas merupakan migran, maka asimilasi menurut Blau, lebih sulit terwujud.

Dengan demikian, asimilasi akan lebih mungkin terjadi di antara kelompok mayoritas (Dayak) dengan kelompok minoritas (Jawa), manakala kelompok minoritas terjadi pada kelompok transmigran, maka akan lebih memungkinkan terjadinya asimilasi dengan kelompok mayoritas (Dayak).

Dalam bahasa lain dapat diungkapkan di sini bahwa masyarakat transmigran Jawa Timur akan terasimilasi oleh masyarakat Dayak, karena menurut Blau (1977: 98-99), Dayak adalah merupakan kelompok mayoritas/superordinat yang memiliki budaya dominan dan akan mampu mewarnai kehidupan kelompok minoritas/subordinat yaitu orang-orang transmigrasi yang hidup di Rasau Jaya Kabupaten Kubu Raya, Kalimantan
Barat. Dengan jumlah yang memang mayoritas dan budayanya telah mengakar pada masyarakat luas tersebut, maka akan mampu mempengaruhi pengetahuan, sikap dan perilaku kelompok minoritas tersebut.

4. Model Empirik Asimilasi Nilai Kekeluargaan dalam Keluarga

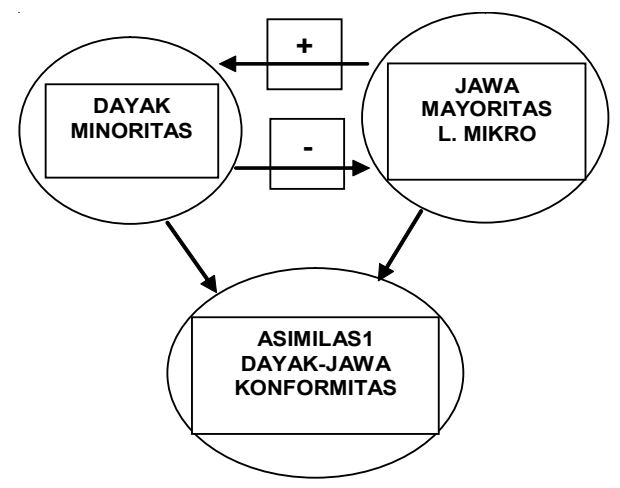

Gambar 4. Model Empirik Hasil Penelitian Asimilasi Dayak-Jawa (Model Pengembangan).

Dari data empirik hasil temuan di lapangan, ternyata dalam keluarga Kusri-Emi (Jawa-Dayak), hidup dan berkembang pemikiran, sikap dan perilaku yang cenderung mengarah pada kebiasaan, dan adat Jawa yang dibangun melalui kompromi-kompromi antara suami-istri. Nilai-nilai kekeluargaan yang konformitas ini dimaksudkan sebagai nilai-nilai yang dibangun bersama oleh suami-istri, dan juga oleh faktor kebiasaan, adat, dan lingkungan sosial budaya setempat antara Dayak dan Jawa, di mana keduanya saling memahami, saling menyesuaikan, dan melakukan kompromikompromi yang mengarah pada jalan tengah, rukun, dan sesuai etika kebijaksanaan (Haryono.P., 1993: 4446).

Sebagai contoh dalam melakukan transformasi dan penerapan nilai-nilai kekeluargaan adalah yang berke-naan dengan sistem perkawinan yang dilakukan di Rasau Jaya merupakan kombinasi sistem perkawinan antara Melayu, Dayak dan Jawa, dengan sistem menggunakan uang asap dapur sebagai bantuan calon suami kepada pihak mempelai calon istri. Hal ini merupakan adat dan kebiasaan warga Melayu yang masuk dalam tradisi perkawinan Jawa-Dayak.

Sementara budaya Jawa dalam prosesi resepsi perkawinan biasanya pihak mempelai perempuan, adalah yang membiayai sepenuhnya pesta perkawinan itu. Hal ini sebagai bagian proses transformasi dan implementasi dari nilai kekerabatan, yang intinya menguatkan kembali tali hubungan antarkerabat dari kedua belah pihak.

Faktor lain yang tak kalah pentingnya adalah keluarga Emi menyesuaikan dengan kebiasaan dan 
adat kehidupan masyarakat Jawa Timur dalam memecahkan masalah-masalah tentang asimilasi nilai kekeluargaan lintas etnik tersebut, di mana keluarga Emi mengadopsi nilai-nilai kekeluargaan Jawa. Hal ini bisa dimaklumi karena lingkungan sosial keluarga Emi yang orang Dayak, hampir sepenuhnya didominasi lingkungan keluarga Jawa yaitu Kusri. Dengan demikian, keluarga Emi hampir sepenuhnya mengadopsi nilai-nilai kekeluargaan Jawa dalam kehidupan seharihari.

Namun demikian, proses kawin campur/pembauran ini dengan seluruh aspek nilai-nilai kekeluargaan yang dipraktikan dalam kehidupan sehari-hari antara kedua kelompok lintas etnik, sebagaimana telah dipaparkan dalam bagian pembahasan, masing-masing rumpun etnik tersebut didasari oleh falsafah, kebiasaan dan adat yang relatif berbeda satu dengan yang lain, tetapi masing-masing etnik, memiliki persepsi dan pemahaman terhadap hakikat nilai-nilai kekeluargaan yang sangat mirip satu dengan yang lain. Dengan demikian, proses asimilasi keduanya tidak mengalami hambatan dan kendala yang berarti.

Temuan penelitian ini juga merupakan bagian dari pengembangan teori asimilasi yang terdahulu, yang memiliki fokus pembahasan yang relatif berbeda dengan yang dilakukan penulis lain. Sebagai contoh, teori asimilasi yang dijelaskan oleh Gordon (1964); Hirsman (1983); Yinger (1985); dan Kulczycki dan Lobo (2003: 203), memfokuskan pada tingkatan-tingkatan asimilasi, di antaranya mengkaji pengaruh tempat kelahiran, bagian dari keturunan Arab yang berasimilasi, dan tingkat penguasaan bahasa Inggris sebagai alat komunikasi yang memungkinkan imigran Arab, mampu bergaul dengan host/etnik tuan rumah (warga Amerika).

Sementara itu, penelitian ini hanya memfokuskan pada nilai-nilai kekeluargaan etnik Melayu, Dayak, dan Jawa, yang belum pernah menjadi kajian peneliti lainnya. Dengan demikian, dapat dikatakan penelitian ini merupakan pengembangan dari penelitian sebelumnya.

Dalam penelitian ini juga ditemukan bahwa keluarga Ela melakukan penyesuaian diri dengan kebiasaan dan adat yang berlaku di Desa Rasau Jaya, dengan menggunakan bahasa Jawa sebagai komunikasi antaranggota keluarga, dan juga belajar dengan tetangga orang Jawa. Berbagai nilai keluarga yang dibangun berorientasi pada kehidupan sehari-hari yang terjadi di desa Jawa yaitu desa transmigrasi tersebut.

Untuk itu dalam gambar 4, Jawa Timur diberi label mayoritas/dominan/superordinate dalam tataran mikro, yang mengandung makna bahwa dalam transformasi dan implementasi nilai-nilai kekeluargaan di lingkungan keluarga kawin campur tersebut, adalah cenderung berorientasi pada kebiasaan dan adat orang-orang Jawa. Sementara itu, kebiasaan dan adat Melayu di dalam keluarga campuran ini mengunakan label subordinat/ minoritas. Alasannya adalah sederhana dan mudah terukur, yaitu lingkungan kultural dan sosial di Desa Rasau Jaya, adalah didominasi budaya Jawa Timur.

5. Model Teoretik Asimilasi Nilai Kekeluargaan dalam Keluargaan Dayak-Melayu

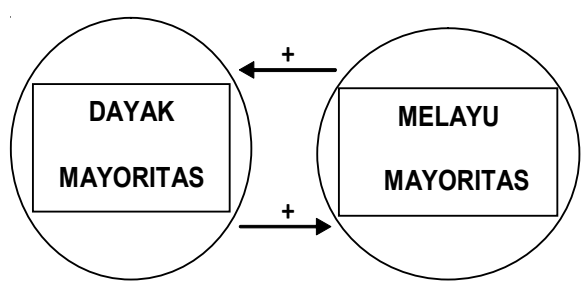

Gambar 5. Model Teoretik Asimilasi Peter Blau (1977)

Menurut model teoretik Blau (1977: 98-99), seperti dikutip oleh Idi (2008: 40), yang terlihat pada gambar 5, menunjukkan bahwa masyarakat akan terintegrasi/terasimilasi, apabila ada suatu keadaan yang dalam konteks struktur sosial menunjukkan kecenderungan parameter-parameternya saling berinterseksi. Sebaliknya bilamana keadaan struktur sosial menunjukkan parameter-peremeternya yang cenderung ke arah konsolidasi, maka integrasi/asimilasi suatu masyarakat akan sulit terjadi.

Blau menegaskan bahwa, dalam hubungan mayoritas (host-Melayu) dan mayoritas (host-Dayak), ukuran besar/kecilnya suatu kelompok mengindikasikan kemungkinan terjadinya integrasi/asimilasi. Jika kelompok mayoritas keduanya merupakan penduduk asli dalam konteks ini warga Melayu-Dayak, maka asimilasi kelompok etnis mayoritas/Dayak ke dalam etnis yang sama-sama mayoritas/Melayu, masingmasing etnik memiliki tingkat kemungkinan yang relatif sama.

Berdasar pada gambar 5 , keduanya memilki kemungkinan yang relatif sama untuk saling berasmilasi dari Melayu ke Dayak, atau sebaliknya dari Dayak ke Melayu berdasarkan besarnya saiz yang berimbang, dan keduanya sama-sama penduduk asli yang masingmasing memiliki pengaruh budaya dominan yang relatif luas. Dengan kata lain, semakin berimbangnya besaran saiz suatu etnik, maka akan menghasilkan tingkat asimilasi yang relatif berimbang pula.

6. Model Empirik Asimilasi Nilai Kekeluargaan dalam Keluarga Dayak- Melayu (Dayak Minoritas-Melayu Mayoritas). 


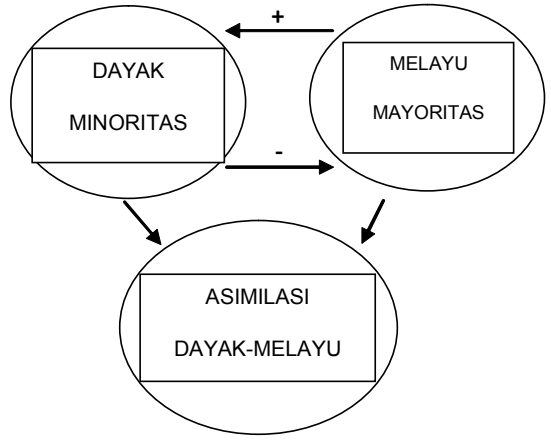

Gambar 6. Model Empirik Hasil Penelitian Asimilasi Nilai Kekeluargan Dayak-Melayu

Dari data empiris hasil temuan di lapangan, ternyata dalam keluarga Pura-Nurti (Dayak-Melayu), telah hidup dan berkembang pemikiran, sikap dan perilaku yang cenderung mengarah pada kebiasaan, dan adat Melayu yang berdasar nilai Islam, yang dibangun melalui cara-cara kompromi-kompromi, dan persuasif antara suami-istri. Nilai-nilai kekeluargaan yang konformitas ini, dimaksudkan sebagai nilai-nilai yang dibangun bersama oleh suami-istri, dan juga oleh faktor kebiasaan, adat, dan lingkungan sosial budaya setempat antara Dayak dan Melayu, di mana keduanya saling memahami, saling menyesuaikan, dan melakukan kompromi-kompromi yang mengarah pada kebiasaan, adat, dan nilai-nilai Islam.

Sebagai contoh dalam melakukan transformasi dan penerapan nilai-nilai kekeluargaan, adalah yang berkenaan dengan sistem perkawinan yang dilakukan Pak Pura dalam mengawini Nurti, adalah mengikuti sistem perkawinan Melayu, dengan sistem menggunakan uang asap dapur sebagai bantuan calon suami kepada pihak mempelai calon istri. Hal ini merupakan adat dan kebiasaan warga Melayu yang masuk dalam tradisi perkawinan Dayak-Melayu.

Dengan demikian, keluarga Pua-Nurti hampir sepenuhnya mengadopsi nilai-nilai kekeluargaan Islam dalam kehidupan sehari-hari, sebagaimana yang dianut dan dipraktikkan dalam masyarakat Melayu di Rasau Jaya.

Hal ini diperkuat oleh temuan penelitian relevan terdahulu (Sukmana, 2003: 115), yaitu warga etnis Arab dan Jawa di Kampung Embong Arab adalah (1) adanya kedekatan antara tokoh masyarakat, baik tokoh dari etnis Arab maupun tokoh dari etnis Jawa; (2) adanya kesamaan agama (relatif beragama Islam); (3) adanya proses perkawinan campuran antara warga etnis Arab dan Jawa; (4) adanya kekompakan dan kegotongroyongan; (5) kesadaran etnis Arab untuk mengikuti aturan setempat (proses pembauran); (6) adanya unsur perasaan persaudaraan antar sesama warga, baik di antara sesama etnis Arab maupun Jawa; dan (7) rasa saling menghormati \& menghargai.

Dari temuan penelitian di atas dapat digambarkan dalam bentuk tabulasi tingkat asimilasi nilai kekeluargaan lintas etnik yang terjadi di desa Rasau Jaya. Tabel 1 , menggambarkan tentang tingkatan-tingkatan proses asimilasi lintas etnik yang terjadi antara Dayak-Jawa, Melayu-Jawa, dan Dayak Melayu selama masa permukiman warga trans Jawa Timur mulai tahun 1973-2010, yang dapat dipaparkan dalam tabel berikut.

Tabel 1. Tingkat Asimilasi Lintas Etnis di Rasau Jaya Menurut Kriteria Gordon (1964).

\begin{tabular}{|c|l|l|l|}
\hline No. & \multicolumn{1}{|c|}{ Jenis } & \multicolumn{1}{|c|}{ Pengertian } & \multicolumn{1}{c|}{ Bentuk } \\
\hline 1. & Akulturasi & $\begin{array}{l}\text { Perubahan yang terjadi } \\
\text { pada masing-masing } \\
\text { pasangan baik sebagian } \\
\text { atau keseluruhan. }\end{array}$ & $\begin{array}{l}\text { Partisipasi } \\
\text { seseorang dalam } \\
\text { pekerjaan, } \\
\text { bahasa, sistem } \\
\text { perkawinan, } \\
\text { peralatan hidup, } \\
\text { dan kepercayaan. }\end{array}$ \\
\hline 2. & Sruktural & $\begin{array}{l}\text { Partisipasi seseorang } \\
\text { dalam ekonomi, } \\
\text { pendidikan dan sosial } \\
\text { kemasyarakatan. }\end{array}$ & $\begin{array}{l}\text { Partisipasi } \\
\text { seseorang dalam } \\
\text { ekonomi dan } \\
\text { pendidikan } \\
\text { asosiasi sosial } \\
\text { kemasyarakatan. }\end{array}$ \\
\hline 3. & Amalgamasi & $\begin{array}{l}\text { Penyatuan dua lebih etnik } \\
\text { secara pisik }\end{array}$ & $\begin{array}{l}\text { Membangun } \\
\text { rumah tangga, } \\
\text { Saling kasih } \\
\text { mengasihi, } \\
\text { melakukan kawin } \\
\text { campur. }\end{array}$ \\
\hline 4. & Identifikasi & $\begin{array}{l}\text { Rasa } \\
\text { Kebangsaan/kedaerahan }\end{array}$ & $\begin{array}{l}\text { Senasib } \\
\text { sebangsa anak } \\
\text { bangsa setanah } \\
\text { air menjalani } \\
\text { hidup }\end{array}$ \\
\hline
\end{tabular}

Sumber: Hasil analisis data penelitian tingkatan Asimilasi Lintas Etnik menurut kriteria Gordon (Wanto Rivaie, 2011: 255).

Pada Tabel 2, temuan penelitian mengindikasikan bahwa transformasi nilai-nilai kekeluargaan lintas etnik yang terjadi di Desa Rasau Jaya berdasarkan kriteria Dewantara, trasformasi nilai-nilai dimaksud berlangsung melalui pembinaan rasa persatuan dalam bentuk kegiatan cinta kasih yang murni dan menghambakan diri. NMNr, dalam bentuk kegiatan membina aturan, disiplin, musyawarah mufakat diwujudkan dalam bentuk kegiatan keterbukaan, persamaan hak, dan saling menghargai; kekerabatan dalam bentuk intensitas hubungan kerabat istri-suami, tidak membedakan dalam membina hubungan kerabat suami-isteri, dan rasa solidaritas dalam bentuk kegiatan membina saling membantu, partisipasi aktif dalam pemecahan masalah, dan berbagi rasa dalam suka dan duka. Hal-hal tersebut dapat dipaparkan dalam Tabel 2 berikut ini. 
Asimilasi Nilai Kekeluargaan...

Tabel 2. Transformasi Nilai Kekeluargaan Lintas Etnis di Rasau Jaya Menurut Kriteria Dewantara (1962).

\begin{tabular}{|l|l|l|l|}
\hline No. & \multicolumn{1}{|c|}{ Jenis } & \multicolumn{1}{c|}{ Pengertian } & \multicolumn{1}{c|}{ Bentuk Kegiatan } \\
\hline 1. & $\begin{array}{l}\text { Nilai } \\
\text { Persatuan }\end{array}$ & $\begin{array}{l}\text { Perpaduan untuk } \\
\text { kemuliaan } \\
\text { keluarga }\end{array}$ & $\begin{array}{l}\text { Rasa persatuan, } \\
\text { Cinta kasih murni, } \\
\text { menghambakan diri, }\end{array}$ \\
\hline 2. & NMNr & $\begin{array}{l}\text { Pedoman bagi } \\
\text { perilaku bersama }\end{array}$ & $\begin{array}{l}\text { Membina aturan, } \\
\text { disiplin, nilai-nilai, } \\
\text { aturan berdasar cinta } \\
\text { kasih dalam } \\
\text { keluarga. }\end{array}$ \\
\hline
\end{tabular}

\begin{tabular}{|l|l|l|l|}
\hline No. & \multicolumn{1}{|c|}{ Jenis } & \multicolumn{1}{|c|}{ Pengertian } & \multicolumn{1}{|c|}{ Bentuk Kegiatan } \\
\hline 3. & Ilusyawaran & $\begin{array}{l}\text { Kesejanteraan } \\
\text { bersama da- } \\
\text { lam keluarga }\end{array}$ & $\begin{array}{l}\text { keterbukaan, } \\
\text { persamaan hak, } \\
\text { saling menghargai }\end{array}$ \\
\hline 4. & Kekerabatan & $\begin{array}{l}\text { Hubungan dari } \\
\text { keturunan nenek } \\
\text { moyang yang } \\
\text { sama }\end{array}$ & $\begin{array}{l}\text { Intensitas hubungan } \\
\text { kerabat istri/suami }\end{array}$ \\
\hline 5. & Solidaritas & $\begin{array}{l}\text { Kemurahan hati } \\
\text { antar sesama } \\
\text { Anggota krluarga }\end{array}$ & $\begin{array}{l}\text { Saling membantu, } \\
\text { berbagi rasa, } \\
\text { berpartisipasi } \\
\text { memecah } \\
\text { kan masalah }\end{array}$ \\
\hline
\end{tabular}

Sumber: (Rivaie, 2011:256).

\section{KESIMPULAN}

Dalam bagian ini, paparan hasil penelitian akan difokuskan untuk menjawab pertanyaan-pertanyaan penelitian, baik yang menyangkut pertanyaan yang bersifat umum dan permasalahan yang bersifat khusus. Selanjutnya, pada bagian berikutnya akan dipaparkan tentang rekomendasi sebagai upaya memberikan masukan tentang pengembangan untuk pengkajian asimilasi nilai kekeluargaan lintas etnik di masa mendatang.

Berdasarkan data temuan penelitian, yang telah dipaparkan pada bagian deskripsi data dan pembahasan hasil penelitian terdahulu, maka dapat ditarik beberapa kesimpulan penelitian sebagai berikut.

Data hasil penelitian menunjukkan bahwa proses asimilasi nilai-nilai kekeluargaan, Dayak-Jawa, MelayuJawa, dan Dayak-Melayu, dilakukan melalui transformasi dan pembinaan, persatuan keluarga, nilai moral dan norma, musyawarah dan mufakat, kekerabatan dan solidaritas atau kemurahan hati, sehingga menghasilkan tingkat asimilasi akulturasi, struktural dan amalgamasi di Desa Rasau Jaya Kabupaten Kubu Raya Kalimantan Barat.

Proses transformasi dan implementasi nilai-nilai kekeluargaan dalam asimilasi lintas etnik, dilakukan dengan cara kompromistis dan persuasif antara suamiistri, antara orang tua dan anak-anak, dan juga antara anak dengan anak serta kerabat. Dalam proses transformasi nilai-nilai kekeluargaan lintas etnis tersebut, ternyata mereka mengalami kendala-kendala antara lain keterbukaan dalam menyatakan pendapat yang belum optimal, kesalahpahaman suami istri, pengaruh negatif lingkungan teman sebaya, kepercayaan pada dukun untuk mengobati penyakit, penguasaan bahasa Jawa kromo, bantuan kepada kerabat, dan jarak tempat tinggal kerabat yang relatif jauh.

Upaya mengatasi kendala oleh kepala desa dan tokoh masyarakat, secara tidak langsung dilakukan bersama masyarakat. Secara formal, tidak ada program khusus untuk mengoptimalisasikan asimilasi nilai kekeluargaan, namun kesadaran masyarakat tergolong cukup menggembirakan dengan dilakukan berbagai kegiatan untuk membangun hubungan sosial lintas etnis yang lebih manusiawi, yaitu melalui kegiatan PKK, arisan warga, koperasi desa, olah raga dan seni rakyat, serta majelis ta'lim.

Dari kesimpulan yang telah dipaparkan di atas, tentang asimilasi nilai-nilai kekeluargaan lintas etnik, beberapa rekomendasi akan dipaparkan pada bagian berikut.

Proses asimilasi nilai kekeluargaan antara Dayak-Jawa, Melayu-Jawa, dan Dayak-Melayu, telah terbukti dapat melakukan pembinaan nilai persatuan, $\mathrm{NMNr}$, musyawarah-mufakat, kekerabatan, dan solidaritas, hal ini diharapkan dapat dipertahankan dan dioptimalkan di masa mendatang, untuk memperkokoh persatuan dan integrasi kelompok-kelompok masyarakat yang plural dan multikultur.

Kendala-kendala asimilasi dan nilai-nilai kekeluargaan yang telah berhasil diatasi oleh keluarga kawin campur, sebaiknya di masa mendatang dapat diantisipasi oleh mereka yang melakukan perkawinan lintas etnik. Dengan demikian, asimilasi nilai kekeluargaan yang menjadi fokus pembinaan dalam keluarga mereka akan dapat berjalan lebih optimal.

Bahwa kepala desa dan tokoh masyarakat belum secara formal merencanakan asimilasi nilai kekeluargaan lintas etnik. Hal ini dapat disubstitusikan melalui berbagai bentuk kegiatan kelompok masyarakat yang sudah ada, untuk lebih diintensifkan sehingga dapat menikmati aktivitas-aktivitas sosial dan budaya yang tersedia di lingkungan hidup mereka, untuk lebih mengenal satu sama lain dan mendekatkan hubungan sosial di antara mereka sehingga kelompok-kelompok masayarakat yang ada akan terjalin hubungan yang lebih erat dan lebih bermakna serta manusiawi.

Penelitian ini memberikan implikasi berupa bagi pembuat kebijakan, hasil penelitian ini mengindikasikan bahwa masih terdapat adanya kendala-kendala, berupa 
pemikiran-pemikiran kalangan orang-orang tua (khususnya warga Dayak), bahwa mereka masih berharap agar anak-anak mereka bisa kawin dengan orang-orang Dayak yang sesuku misalnya Dayak Kenyah, sekurang-kurangnya sepupu dua atau tiga kali. Faktor lain yang bisa menjadi kendala juga berupa pernyataanpernyataan kalangan tertentu (elit partai), yang mengatasnamakan etniknya dengan memunculkan label anak daerah dan bukan anak daerah. Dua hal ini menjadi tugas pemerintah daerah bersama DPRD, untuk bisa menghilangkan image yang bisa berdampak negatif terhadap proses asimilasi lintas etnik di masa depan.

Kendala-kendala tersebut, bisa menjadi sekatsekat yang semakin tebal dan bersifat laten, yang sewaktu-waktu dapat muncul ke permukaan menjadi konflik sosial, sesuai dengan temperatur dan suhu politik yang sengaja digulirkan oleh oknum-oknum tertentu, untuk mengambil keuntungan pribadi atau kelompok.

Sedangkan bagi pengguna hasil penelitian, baik kalangan akademisi maupun masyarakat luas, penelitian ini sifatnya masih terbatas, baik dari jumlah sampel maupun lingkup materinya, yaitu mengkhususkan diri pada nilai-nilai kekeluargaan. Dengan demikian, hasilhasil penelitian ini dimungkinkan dapat diterapkan dalam lingkup yang terbatas pula. Penerapan hasil-hasil penelitian yang tidak sesuai dengan karakteristik subjek dan materi penelitian dapat menghasilkan hasil analisis yang kurang akurat dan dapat menyimpang dari konteks permasalahan yang menjadi fokus analisis.

Untuk peneliti berikutnya, perlu lebih memahami aspek-aspek kemasyarakatan yang lebih luas, untuk membuka tabir berbagai masalah-masalah yang menyebabkan adanya hubungan-hubungan sosial yang ada menjadi tidak harmonis dan munculnya konflik horizontal dikalangan pada berbagai kelompok. Misalnya mengkaji lebih jauh tentang asimilasi pada komunitaskomunitas lokal, maupun komunitas partai politik, dan komunitas kegamaan di tingkat lokal, sejauhmana proses asimilasinya hak-hak politik, keagamaan, dan semacamnya, karena materi kajian ini juga seringkali menjadi maslah-masalah yang serius sehingga muncul konflik horizontal antara berbagai kalangan masyarakat, yang bisa mengancam integrasi nasional. Kajian-kajian dalam hal ini, dimungkinkan akan dapat memberikan sumbangan yang sangat berharga bagi pengembangan, dan pengayaan ilmu kemasyarakatan yang sedang mengalami perubahan-perubahan besar yang sedang terjadi saat ini.

\section{DAFTAR PUSTAKA}

Abecrombie,N.,et.al. (1986) Sovereign individual and capitalism. London: Allen \& Urwin.

Alwasilah, A. C. (2008). Pokoknya kualitatif. Jakarta: Pustaka Jaya.

Blau, P.M. (1977). Inaquality and heterogeneity: A primitive theory of social structure. New York and London: The Free Press. And Mc. Millan Pub.

Dewantara, K.H. (1962). Pendidikan keluarga. Yogyakarta: Taman Siswa Press.

Dewantara, K. H. (1962). Hidup keluarga sebagai sendi persatuan.Yogyakarta: Taman Siswa Press.

Dewantara, K.H. (1962). Pengaruh keluarga terhadap hidup tumbuhnya budi-pekerti. Yogyakarta: Taman Siswa Press.

Dewantara, K.H. (1962). Keluarga sebagai pusat pendidikan. Yogyakarta: Taman Siswa Press.

Dwiarso,K.P. (2008). Taman siswa untuk nation and character building. Yogyakarta:Taman Siswa Press.

Emzir, M. (2010). Metode penelitian pendidikan kualitatif dan kuantitatif. Jakarta: Radjawali.

Gordon, M.M. (1964). Asimilation in American life, the role of race, religion, and national origins. New York: Free Press.
Gordon, M.M. (1981). Toward a general theory of racial and ethnic group relations. London: Harvard University Press.

Haryono,P. (1993). Kultur Cina dan Jawa. Jakarta: Pustaka Sinar Harapan.

Idi, A. (2009). Asimilasi Cina Melayu di Bangka. Yogyakarta: Tiara Wacana.

Kades. (2010). Monografi desa. Rasau Jaya.

Khaeruddin,H.S.S. (2008). Sosiologi keluarga. Yogyakarta: Liberty.

Kulczycki, A. \& Lobo, A. P. (2002).Patterns, determinants, and implications of intermarriage among Arab Americans. Journal of Marriage and Family, January V. 64, p.202-210. New York: Stanford University.

Lemore, Mc.S.D. (1983). Racial and ethnic relations in America. London: Allyn and Bacon.

Mulyana, D. (2006). Metodologi penelitian kualitatif (Paradigma baru ilmu komunikasi dan ilmu sosial lainnya). Bandung: Remaja Rosdakarya.

Purwahadiwardoyo.(1965). Pendidikan nilai untuk membangun karakter. Yogyakarta: Taman Siswa.

Rivaie, W. (2011). Asimilasi nilai kekeluargaan lintas 
etnis. Disertasi. Bandung: UPI Bandung. Tidak diterbitkan.

Rosenfeld, M.J. (2002). Measures of assimilation in the marriage market: Mexican Americans (19701990). Journal of Marriage and Family, February V. 64, No. 152, p.152-162.. New York: Stanford University.

Sarjono.M.A. (1992). Paham Jawa. Jakarta: Swadaya Sartre, J.P.(1936). Being and nothingness. New York:
The Modern Library.

Sauri S. \& Herlan F., (2010). Meretas pendidikan nilai. Bandung: Arfino Raya.

Sukmana, O. (2003). Proses asimilasi sosial dalam komunitas masyarakat bauran etnis Arab-Jawa (Studi di kampung Embong Arab, kota Malang). 24 Juni. Malang: Lembaga Penelitian Malang. Syah, K. (2010). Family values. Journal of Marriage and Family, V. 10, p. 3-5. 